\title{
Jiri Pelikan
}

\section{Debatten i den sovjetiske opposition i dag og det vesteuropæiske venstres ansvar}

Ofte hører jeg følgende i venstreforsamlinger i Vesteuropa: „Vi kan stå solidariske med Grigorenko og Medvedev, men ikke med Solsjenitsyn, for han er ikke socialist og har konservative synspunkter." Jeg svarer således: "I har bestemt ret til at føle jer nærmere forbundet med Grigorenko og Medvedev, for de bekender sig til socialisme og marxisme, men netop som socialister må I forstå, at friheden ikke kan opdeles; Grigorenko og Medvedev udgør en bestanddel af den sovjetiske opposition, ligesom Solsjenitsyn, Sacharov, Bukovskij, Amalrik, men ogå de ukrainske nationalister, de kristne, jøderne, ja, ganske enkelt alle, hvis rettigheder undertrykkes, og som kun bliver bragt til tavshed og forfulgt, fordi de har en anden mening om, hvordan Sovjetunionen skal regeres, end den eneste officielle linie. Netop derfor må det vesteuropæiske venstre, socialister og revolutionære, kæmpe for tankefrihed for den samlede sovjetiske opposition, for det bliver ikke muligt at udfolde hverken en virkelig diskussion og polemik eller den politiske kamp, før oppositionen får legalitet.«

Det gælder så meget desto mere som vi stadigvæk ved meget lidt om den sovjetiske opposition. De ovennæunte navne, som er trængt ind i bevidstheden i den vestlige offentlighed, udgør nemlig kun toppen af wisbjerget «. Jo større en del, der vil kunne "dukke op “ på det offentlige livs overflade, jo mere differentieret vil billedet af den sovjetiske opposition blive, og jo større vil dens positive bidrag til diskussionen om udviklingen i USSR og demokratiets og socialismens udvikling overhovedet kunne være. Derfor burde solidaritet med den samlede sovjetiske opposition, afvisning af administrative former for politisk kamp og entydig støtte til kravet om, at såvel Solsjenitsyn som Grigorenko og alle de øvrige får lov til at offentliggøre og udtale deres meninger og tanker i USSR, være enhver virkelig socialists første, grundlæggende reaktion på den eksisterende repression af folk med afvigende meninger i USSR og på den modige kamn, som fores af Solsjenitsyn og Grigorenko, af Medvedev og Bukovskij og andre. 
Man kan imidlertid ikke vente, indtil det lykkes at bryde med ideen om et eneste politisk partis magtmonopol. Differentieringen begynder nemlig allerede i dag under den kraftige repressions vilkår. Solsjenitsyns brev til de sovjetiske ledere, som blev vurderet kritisk af akademimedlem Sacharov, og Roy Medvedevs marxistiske polemik viste først for nylig helt offentligt, at der inden for den sovjetiske opposition eksisterer en bred skala af meninger om årsagerne til sovjetsamfundets nuværende krise og også om perspektiverne for de mulige forandringer. Dette er imidlertid ikke tegn på svaghed, som det ængsteligt hviskes af mange vestlige kommentatorer, og som det sejrsbevidst udråbes af den officielle sovjetiske propaganda, men netop det stik modsatte - det er udtryk for vitaliteten i en bevægelse, der først er ved at begynde sin udvikling.

Denne forskellighed i standpunkter og tit også en voldsom polemik - som på ingen måde bryder solidariteten i kampen mod repressionen - er bevis for, at vi for forste gang i årtier kan være vidne til, at der opstår et nyt, parallelt politisk liv i USSR, som er begrundet i behovet for at være informeret, for diskussion om de faktiske problemer og for genfødsel af politisk tænkning.

Den vestlige offentligheds største opmærksomhed koncentrerer sig om Alexander Solsjenitsyn. Det er også omkring ham, at de fleste polemikker er opstået. Men overraskende nok går diskussionen kun $\mathrm{i}$ ringe grad på denne ubestridt største nulevende russiske forfatters litterære værk. Hele diskussionen drejer sig om "Archipel GULag« og om »Brev til Sovjetunionens ledere«, som om alle ville glemme, at Solsjenitsyn er forfatter, kunstner, ikke politiker, og at det derfor er hans litterære værk, der er afgørende, ikke hans politiske anskuelser.

Dette er særlig overraskende hos kommunister, der bekender sig til arven efter Lenin, og som i Geneve i 1974 med repræsentanter for de vestlige kommunistiske partier som talerør stemplede Solsjenitsyn som "reaktionær" udelukkende på grund af hans politiske anskuelser og uden nogen form for seriøs analyse af hans litterære skaben. Lenin bedømte forfattere på en ganske anden måde; det bevidner hans vurdering af Tolstoj, der var konservativ i sine politiske anskuelser og reaktionær i forhold til sin tid, men som i sine værker afdækkede modsætningerne i det zaristiske samfund og på den måde varslede revolutionens komme.

Det er dog vel ikke muligt, at marxisterne ikke ser, at også Solsjenitsyn holder spejlet op for det sovjetiske samfund og i dramatisk form afdækker dets modsætninger. På den måde maner han til overvindelse af disse modsætninger, og derfor virker hans værk objektivt revolutionært, progressivt, mod stagnation og status 
quo. Det burde være hovedkriteriet for den marxistiske kritik af Solsjenitsyn.

Dette ændrer intet ved den kendsgerning, at Solsjenitsyn er konservativ i sine politiske anskuelser, især som han fremlagde dem $i$ "Brev til Sovjetunionens ledere" og delvist i "Archipel GULag": Han afviser den marxistiske ideologi som fremmed for Rusland og importeret med magt, han ser det eneste gyldige system med moralsk værdi i den ortodokse kristendom, og vejen ud af den nuværende krise ser han i radikal tilbagevenden til overvejende agrare livsformer, bondeproduktion og -kultur, i resignation over for et imperium af mange nationer, og altsammen under bibeholdelse af et autoritært regeringssystem. Solsjenitsyn opfordrer de nuværende herskere i USSR til at kaste den marxistiske ideologi fra sig og overlade den til modstanderne (her tænker han på Kina); det begrunder han således: "Denne ideologi svækker og binder jer kun!^ Denne opfordring er imidlertid ikke så absurd som den ser ud til: I virkeligheden volder marxismen blot vanskeligheder for den russiske stormagts nuværende herskere, selv om de formelt ikke kan give afkald på den, fordi den tjener dem som ideologisk flag i deres stormagtspolitik.

Det er forståeligt, at sådanne anskuelser hos den ene part fremkalder et skadef ro smil, hos den anden - især en del af venstrefløjen en direkte tilfredshed over, at det nu omsider er muligt offentligt at skille sig af med Solsjenitsyn og således unddrage sig den i den grad ubehagelige diskussion, som er udsprunget af misbilligelsen af, at han og andre bliver undertrykt. Hertil kommer så højrekræfternes ukritiske bifald og den publicity, de giver Solsjenitsyn, i deres anstrengelser for at spænde ham for deres vogn som den yngste forstærkning i kampen mod socialismen, den socialisme, der begynder at banke på Vesteuropas porte. Alt dette er nok til, at mange mennesker og partier, som bekender sig til marxismen, betragter "tilfældet Solsjenitsyn " som afsluttet. Det var også, hvad den sovjetiske ledelse håbede på, da den besluttede sig til at udvise Solsjenitsyn til vesten (næsten et halvt århundrede efter den første politiske deportation - af Leo Trotskij).

Den sovjetiske propaganda gjorde sig og gør sig umage med at skildre Solsjenitsyn som "ekshibitionist “, som en enkeltperson, der er fuldstændig isoleret fra befolkningen. Men hvis det var tilfældet, hvordan skal man så forklare intensiteten og den massive karakter af kampagnen imod ham, den spektakulære afgørelse om hans udvisning og den vedvarende polemik om ham? Det forer til spørgsmålet: Hvor stor er Solsjenitsyns indflydelse egentlig, og i hvilket omfang genspejler hans ideer en bredere sovjetisk offentligheds anskuelser? 
Det ville kun kunne vise sig, hvis Solsjenitsyns bøger offentliggiordes i USSR, og hvis der kunne udfolde sig en fri diskussion om dem. Dette tillod det sovjetiske bureaukrati imidlertid ikke - måske med "god" grund. Det er derfor malplaceret, når repræsentanter for nogle vestlige kommunistiske partier (f.eks. IKP) siger, at de er for offentliggørelsen af "Archipel GULag» i USSR, for »det overvældende flertal af det sovjetiske folk ville afvise Solsjenitsyns anskuelser«.

Selv Roy Medvedev, der polemiserer mod Solsjenitsyns »Brev«, anerkender, at de konservative, nationalistiske og slavofile anskuelser deles af en temmelig stor del af sovjetborgere, der er blevet skuffet af den stalinistiske praksis, og som ikke ser nogen anden udvej end rehabilitering af de gamle russiske moralske værdier. Det ser imidlertid ud, som om Solsjenitsyns ideer dog trods alt $i$ vidt omfang kun har tilslutning hos et mindretal, som især er begrænset til den religiøse opposition, og at Solsjenitsyns betydning inden for USSR først og fremmest skyldtes hans moralske autoritet, der blev styrket af hans internationale anerkendelse og kvaliteten af hans litterære værk. Den sovjetiske ledelse ser med rette ikke hans politiske anskuelser, men derimod forst og fremmest en moralsk integritet, tapperhed og den menneskelige skæbne og den dermed forbundne autoritet som hovedfaren, som "smittekilden«, som hovedcentret for den infektion af nonkonformisme, som for enhver pris må elimineres. Hans resistens, hans modstandskraft mod enhver form for pres førte nødvendigvis til, at modstandskraften styrkedes hos de to andre hovedstrømninger og centrer i den sovjetiske opposition, der i deres perspektiv er meget farligere.

Hvis vi - noget skematisk, hvilket ikke kan undgås i et kort studie opdeler den sovjetiske opposition i tre stromninger, hvor Solsjenitsyn netop repræsenterer den ene, så repræsenterer medlem af videnskabernes akademi, Sacharov, den anden stromning. Man kan betegne den som en i grunden liberal, teknokratisk og humanistisk strømning, der stræber mod en modernisering og europæisering af Rusland. Selv om den orienterer sig mod den vestlige liberalismes teori og praksis, er dens rodder ikke - som hos Solsjenitsyn forankret $\mathrm{i}$ fortiden, men derimod snarere i den sovjetiske nutid, som den er blevet dannet $i$ industrialiserings- og urbaniseringsprocessen. Til forskel fra Solsjenitsyn betragter Sacharov ikke tilintetgørelsen af de traditionelle russiske livsformer som en ulykke; tværtimod tager han udgangspunkt i den som en kendsgerning og bygger sine ideer på erfaringerne fra de industrielle lag i byerne, især på erfaringerne fra ingeniørkadrerne på fabrikkerne, den 
videnskabeligt-tekniske intelligens på forskningsinstitutterne og institutionerne og de nye industrimanagere.

Netop fordi denne strømning retter sig mod disse lag, der er mest afgørende for den sovjetiske økonomi, synes den at være den farligste for det degenererede parasitære bureaukrati. Netop derfor er også denne del af oppositionen, som repræsenteres af Sacharov, politisk realistisk og fremadrettet, for af den kan der vokse nye politiske og økonomiske ledere frem, som vil erstatte det nuværende uduelige partibureaukrati; og med dem vil også den nye økonomisk-politiske struktur kunne dannes, som bygger på en høj arbejdsproduktivitet og en bred demokratisering af det offentlige liv.

Sacharov, der også nyder høj moralsk autoritet som følge af sin principfasthed og sit mod, har klarere forestillinger med det politiske mål med, hvad han gør, og med sin taktik end Solsjenitsyn. I og med at han ser det endelige mål i demokratisering og modernisering af USSR, så ser han det afgørende spørgsmål i den nuværende etape i forsvaret for de demokratiske og borgerlige rettigheder, som er garanteret $\mathrm{i}$ den sovjetiske forfatning, men som der uafladelig begås overgreb imod på grund af magtapparatets vilkårlighed. Derfor dannede han "Komiteen til forsvar for menneskerettighederne«, og han protesterer systematisk mod alle former for repression; her udnytter han sin "ukrænkelighed ", som både skyldes hans tidligere fortjenester og den omstændighed, at den sovjetiske ledelse i den nuværende etape af tilnærmelse til vesten ikke i så høj grad kan tillade sig at ignorere den vestlige offentlige mening, som det var almindeligt under Stalin.

En lang tid lang så det ud som om akademimedlem Sacharov tilskrev det udenlandske pres på den sovjetiske ledelse en alt for stor betydning. Det udnyttede den officielle propaganda - indbefattet nogle klodsede formuleringer fra hans side - til forsøget på at gøre ham til modstander af den internationale afspænding og det okonomiske samarbejde mellem øst og vest. Det er klart, at alt for store forhåbninger til pres udefra altid er udtryk for svaghed hos den indre opposition, der er ude af stand til selv ved egen pression og kamp at sætte bestemte krav igennem. Og foreløbig besidder den sovjetiske opposition selv hverken så meget kraft eller tilstrækkelig tillid til sine egne muligheder, hvad der ikke kan være anderledes efter næsten 50 års autoritært regime uden politisk liv.

Hos Sacharov gør der sig også en vis mangel på umiddelbart kendskab til det vestlige establishment gældende og desuden den illusion, at dette establishments repræsentanter har en eller anden interesse $i$ ændring af status quo og i oprettelse af demokrati i 
USSR. Først lidt efter lidt blev det klart for Sacharov og hans tilhængere, at den internationale pression og afspændingen kun kan skabe gunstigere forudsætninger for demokratiseringsprocessen i USSR, og at man også må søge forbundsfæller for dette mål uden for de regerende kredse, først og fremmest i den fremskridtsvenlige offentlige mening $i$ vesten. Derfor afviser Sacharov den mulighed at rejse til USA, han forstærker sin kamp til forsvar for borgerrettighederne i USSR og hæver oftere og of tere sin rost mod repressionen i andre dele af verden, i Indonesien, i Irak, Chile, Spanien.

I indledningen til den udenlandske udgave af sine taler og afhandlinger reflekterer Sacharov selvkritisk over årsagerne til, at den fremskridtsvenlige offentlige mening $\mathrm{i}$ vesten ikke begriber den sovjetiske oppositions tragiske situation og omvendt: "Mangel på informationer; den kendsgerning, at man, năr man tilhører den sovjetiske opposition, ikke blot er afskåret fra at besøge andre lande, men også fra at bruge flertallet af informationskilder i sit eget land; den omstændighed, at vores eget lands historiske erfaringer har vænnet os fra en overdreven 'venstreradikal' holdning, således at vi vurderer mange kendsgerninger anderledes end den venstreorienterede intelligens i vesten; nødvendigheden af at undgå politiske forklaringer på internationale problemer, som vi ved så lidt om (vi udvikler egentlig ikke engang en politisk aktivitet $i$ vores eget land); nødvendigheden af at løbe den risiko, at vi kommer til at køre i den sovjetiske propagandas spor, som så ofte vildleder os ... Vi retfærdiggør ikke overgreb eller uretfærdigheder, ligegyldig hvor de sker. Og vi tror ikke, at der hos os sker mere af den slags end andre steder. Men indimellem slår vores kræfter ganske enkelt ikke til til hele verden. Derfor kræver vi, at man tager alt dette i betragtning og beder om, at man undskylder os de fejltagelser, som vi kommer til at gøre os skyldige i midt i den støvsky, som hvirvles op af polemikker."

Grunden til, at jeg kommer med så langt et citat, er, at der i disse sæt ninger afspejles en vigtig udvikling, som en del af den sovjetiske opposition gennemløber, og desuden som hjælp til at venstrefløjen i vesten bedre skal forstå dens holdninger. Sacharov hentyder her selvkritisk til nogle unøjagtige formuleringer i telegrammet til juntaen i Chile, som bevidst blev fordrejet af en urigtig oversættelse og udnyttet af den officielle Moskva-propaganda, som desværre også en del af venstrefløjen så brugte som reddende halmstrå for ikke at være nødt til at høre Sacharovs stemme. Hvad ville disse "ortodokse marxister « sige, hvis den sovjetiske opposition i dag foreholdt dem deres blinde forherligelse af den stalinistiske repression, for- 
dømmelsen af Tito som en "fascistisk hund " og mange andre "meningsskift «, som ikke ligger så særlig langt tilbage? Med denne bemærkning vil jeg frem for alt understrege, at det er nødvendigt gensidigt at lære hinanden at kende og forstå hinanden, søge årsagerne til den ene eller den anden holdning - det gælder begge sider, for også i den sovjetiske opposition er der dogmatikere, som bifalder alt det, som den officielle propaganda fordømmer, og som fælder deres domme uden kendskab til den vestlige realitet.

Den tredje stromning i den sovjetiske opposition, hvis politiske repræsentanter er general Grigorenko og teoretikeren Roy Medvedev, står klart på socialistiske positioner. De bygger på den marxistiske ideologi og ser den nuværende tilstand som produkt af Stalins deformering af Lenins lære. Vejen ud af den nuværende krise ser de $\mathrm{i}$ en "tilbagevenden til Lenins normer for parti- og statsliv og den videre udfoldelse af dem«. Ifølge Medvedev er denne strømnings hovedkrav "dybtgående demokratisering af partiet og det sovjetiske samfund overhovedet «.

På hvilken måde adskiller den sig grundlæggende fra den officielle politik? De opfatter ikke marxismen-leninismen som en afsluttet lære, men derimod først og fremmest som en metode til at undersøge den nye virkelighed og dens forandringer. Herom skriver Medvedev: "Marx' og Engels' tilhængere må ikke blive hængende i kun de forestillinger og teorier, som udarbejdedes i det 19. årh. af disse store tænkere. Det samme kan man sige om Lenin og leninismen."

Medvedev betragter socialismen som en "samfundsorden «, hvor den arbejdende befolkning ikke blot er sikret økonomiske og sociale rettigheder, men også alle politiske og borgerlige rettigheder. Det betyder udfoldelse af presse-, ytrings- og forsamlingsfrihed og frihed for kunstnerisk skaben og videnskabelig forskning“. I praksis må dette nødvendigvis føre til en indskrænkning af parti- og statsapparatets magt og dets underordning under de valgte organer. Medvedev betoner, at " $\mathrm{i}$ det socialistiske samfund må man ikke forfølge mennesker med afvigende meninger og medlemmer af oppositionen, for uden retten til opposition kan intet demokrati eksistere «. Efter sovjetiske forhold er dette et meget modigt standpunkt, som beviser, at denne oppositionsstrømning ligger meget tæt op af de tjekkoslovakiske forestillinger om "socialisme med et menneskeligt ansigt «, og at den, hvad angår spørgsmålet om at betone retten til opposition, endda går endnu længere.

Derimod finder vi ikke her nogen særlig stor begejstring for systemet med arbejderråd, som det blev konstitueret på fabrikkerne i Tjekkoslovakiet i 1968. Også de jugoslaviske erfaringer med selv- 
forvaltning ser repræsentanterne for denne strømning snarere på med forbehold, og de bifalder kun dette eksperiment, når det gælder mindre og mellemstore virksomheder, mens de ved de store virksomheder kun ser det som muligt, at abejdere og funktionærer deltager i at løse problemerne om løn og ansatte gennem produktionskontrol.

1 denne og andre henseender åbenbarer der sig hos den sovjetiske opposition en angst for den revolutionare energi, som ville kunne frigøres i masserne, og først og fremmest angst for elementære eksplosioner af utilfredshed, som det godt kunne komme til efter en så lang periode med undertrykkelse og afpolitisering. Det er forståeligt for enhver, der kender den virkelige situation i USSR, som den har udviklet sig i løbet af mere end et halvt århundredes bureaukratisk herredømme. Venstrefløjen i vesten bebrejder ofte den sovjetiske og den østeuropæiske opposition, at den ikke tager warbejderklassens revolutionære opgave " alvorligt. Striden udkæmpes ikke på det teoretiske niveau, hvor enhver anerkender, at arbejderklassen har denne ledende rolle - selv det herskende regime udgiver sig for at repræsentere arbejderklassens interesser.

Men her glemmer man imidlertid, at arbejderklassen i USSR og de øvrige østeuropæiske lande kun i ringe grad ligner arbejderklassen i de kapitalistiske lande, som er stærkt engageret i politiske, faglige og klassemæssige kampe, i strejker, i internationale solidaritetsaktioner osv. 1 modsætning hertil blev arbejderklassen i USSR afpolitiseret og fik berøvet sin klassebevidsthed af det stalinistiske bureaukratiske system. Man fortalte den atter og atter, at den centrale og eneste form for deltagelse i opbygningen af socialismen er at opfylde arbejdsnormerne og de økonomiske planer, som opstilles af partiet, som regerer i arbejderklassens navn. På parti- og fagforeningsmoder taler man derfor uafbrudt om normer, opfyldelse af planen, mangler i produktionen, men næsten aldrig om politik. Konsekvensen er, at den sovjetiske arbejder af i dag ikke kender den politiske kamps tradition, han ved ikke, hvad en strejke er, og at dette er hans mest effektive våben, og han er sig ikke sine interesser som medlem af en klasse bevidst; hans interesse er rettet mod at forbedre sin personlige levestandard.

Dette er grunden til, at Medvedev og de øvrige tilhængere af den socialistiske strømning inden for den sovjetiske opposition, som ikke tror på, at man kan forandre denne tilstand i løbet af den nærmeste fremtid, tager udgangspunkt $i$, at demokratiseringsprocessen i USSR må begyndes og føres "fra oven « - af bevidste og fremskridtsvenlige medlemmer af parti- og statsinstitutionerne, at de såkaldte "parti-demokrater", som Medvedev kalder dem i sin 
bog "Sovjetborgere i opposition. Forsvarsskrift for et socialistisk demokrati« (Claassen Verlag, Hamburg). "Vi kan kun tage udgangspunkt i mulighederne i det samfund, som findes i USSR " siger Medvedev $i$ sit svar på Solsjenitsyns "Brev til lederne $i$ USSR « - »og som hverken er et statskapitalistisk samfund, som nogle påstår, eller et samfund med 'udviklet' og 'fuldbyrdet' socialisme, som andre hævder."

Den slags argumenter fremkalder sædvanligvis mistro og modstand hos venstrefløjen i vesten, som ser det som en åbenbaring af opportunisme og tab af revolutionære perspektiver. Når man imidlertid kender forholdene i USSR og hele den samlede magtmekanisme, ved man, at den reelt eneste farbare vej til at forandre forholdene og til at gennemføre en politik er aktivitet og kamp inden for de bestående institutioner og i første række inden for det monopolistisk handlende parti, som er i besiddelse af den samlede magt. »Parti-demokraterne « går ud fra, at der i udviklingsprocessen også dannes en slags opposition inden for partiet af de funktionærer, som har tættere forbindelse til samfundslivet, og som mærker, at de bureaukratiske strukturer er skadelige, og at det er nødvendigt med forandringer.

Sådan var det under Krutchov efter SUKP's 20. partikongres, og sådan var det under forberedelserne til det $»$ tjekkiske forår «: Impulserne til reformerne og forandringerne kom »fra oven «, og man kæmpede dem igennem inden for partiet. Men man kan drage endnu en lære af erfaringen: mens Krutchov led skibbrud, fordi han ikke forstod i tide at bygge på støtte fra masserne og kun reorganiserede »i toppen «, så vandt det »tjek kiske forår « en så bred støtte i masserne netop takket være den kendsgerning, at der kunne udvikle sig en forbindelse mellem "oppositionen i ledelsen " og bevægelsen i folket. Kun denne forbindelse kunne holde stand mod dogmatikernes og de konservative kræfters intriger, således at forst det sovjetiske militærindgreb kunne standse og kvæle denne bevægelse.

Det er et meget opmuntrende kendetegn, at Medvedev i sin polemik mod Solsjenitsyns »Brev til lederne « indrømmer muligheden af at danne et "nyt socialistisk parti, som vil adskille sig både fra de nuværende socialdemokratiske partier og fra de nuværende kommunistiske partier«. Han håber ganske vist stadigvæk på, at også den officielle ledelse af SUKP vil være i stand til at gennemføre de nødvendige reformer $\mathrm{i}$ retning af en demokratisering, men han forstår, at det er umuligt at vente passivt på denne udvikling, og at det er nødvendigt at fremme den ved et ydre pres, dvs. ved at danne en socialistisk opposition eller endda ved at danne et socialistisk 
parti af en ny type. I eksistensen af dette ser Medvedev muligheden for "genfødsel og helbredelse af SUKP «.

Her når vi til den sovjetiske oppositions grundproblem: Hvordan er det muligt reelt at ændre den nuværende tilstand? Hvilken reel indflydelse kan oppositionen have under betingelser, der ikke engang tillader dens legale eksistens? Det er klart, at under disse betingelser er dens muligheder meget begrænsede, allerede fordi den ikke kan virke $\mathrm{i}$ centrum, men kun i randzonerne, og fordi den ikke har nogen effektive instrumenter til at sætte sin indflydelse igennem med. Den sovjetiske opposition kan protestere mod uret og repression, den kan øve pression ved hjælp af prominente personer eller den udenlandske offentlige mening, men den kan ikke føre nogen systematisk politisk kamp. Den er henvist til at vente at differentieringsprocessen tager form i partiledelsen, den kan øve indflydelse på denne proces, søge og finde forbundsfæller. Men virkeligt virke vil den først kunne, når den er i stand til at optræde som en selvstændig politisk kraft - hvadenten det så bliver i form af et egentligt oppositionelt parti eller en bevægelse eller andre grupperinger med eget program, som ikke kun indeholder en kritik af den nuværende tilstand, men også et alternativ, som flertallet eller en del af befolkningen kan gå ind for.

I dag forekommer denne forestilling naturligvis absurd, og alligevel tror jeg, at den er realistisk, og at den må gøres til hovedmålet for den nuværende oppositionelle bevægelse i USSR og de øvrige østeuropæiske lande på den ene side, og på den anden side for alle socialistiske kræfter i vesten. Det er nødvendigt helt fra grunden af at modbevise den forestilling, som endnu i dag er almindelig udbredt, at det skulle være arven fra Oktoberrevolutionen og Lenin, at der kun bør eksistere ét parti og ikke nogen form for politisk pluralisme, som man i dag fremstiller det i den officielle sovjetiske propaganda - som om denne tilstand skulle være i overensstemmelse med læren fra Marx og Engels eller være et "specifikt karaktertræk«, ved Rusland og Østeuropa, som en del af venstrefløjen bilder sig ind.

I virkeligheden finder vi hverken i Marx' og Engels' skrifter eller i Lenins grundlæggende værker nogen form for teoretiske begrundelser for, at kun ét partis herredømme er den nødvendige garant for proletariatets diktatur. Hos Lenin finder vi ganske vist $i$ de forskellige etaper forskellige formuleringer, hvor mange kan udlægges sådan, at proletariatets diktatur er identisk med ét partis herredømme. Men nogle steder betoner han også, at opløsningen af andre politiske partier og et ét-parti-system kun er en overgangsforanstaltning, som opstår af den konkrete historiske situation, 
dvs. i den situation, hvor revolutionen er truet af borgerkrig og udenlandsk intervention. I princippet indrømmede Lenin muligheden af et system med flere politiske partier under opbygningen af et socialistisk samfund. Ligeledes anså Lenin afskaffelsen af fraktioner og strømninger inden for partiet for at være en tidsbegrænset forholdsregel, som Stalin imidlertid giorde til en jernhård lov. $\mathrm{Og}$ således begyndte man under Stalin og hans efterfølgere at udgive eksistensen af kun ét parti og dets monolitiske karakter for at være en uadskillelig bestanddel og grundpille i den marxistiskleninistiske lære.

Der er altså ingen begrundelser for, at man under den fredelige sameksistens' betingelser, når Sovjetunionen ikke længere er truet af nogen omringning, når den tværtimod er blevet til en verdensmagt, og når den socialistiske bevægelse $\mathrm{i}$ hele verden udvikler sig, holder liv $i$ en anakronisme som tilstedeværelsen af kun ét monopoliseret parti og en jernhård centralisering og disciplin inden for dette parti. Dette er ikke engang teoretisk holdbart: i dag er det almindelig anerkendt, at der også efter en sejrrig revolution endnu længe vil eksistere både forskellige klasser, selv om de ikke vil være antagonistiske, og sociale grupper i befolkningen med forskellige interesser og problemer. For at disse interesser kan komme for dagens lys og gøre sig gældende samtidig med, at man søger fælles løsninger for hele samfundet, må der eksistere politiske og faglige organisationer, som kan udtrykke disse interesser. Alt dette taler for nødvendigheden af politisk pluralisme under socialismen, som på ingen måde kan true det socialistiske system, når der er kollektiv ejendom af produktionsmidlerne.

Flertallet af kommunistiske partier i vesten erklærer i dag, at de stræber mod et andet socialistisk samfund end det sovjetiske, og at de vil garantere politisk pluralisme, ytrings-og organisationsfrihed og mulighed for opposition. Dermed indrømmer de allerede indirekte, at de ikke regner den sovjetiske mreale socialisme" for en "model« eller et »ideal«, som man ubetinget må forsvare og også anvende i andre lande. Men de har ikke mod til klart at sige, at det system, der eksisterer i USSR og de østeuropæiske lande i virkeligheden er udtryk for en deformering af det socialistiske tankegods, og ikke mod til entydigt at tage afstand fra det.

Ganske vist forstår kommunister, socialister og venstrefløjen $\mathrm{i}$ vesten, at det er nødvendigt at demokratisere systemet i USSR, og de onsker også dette, for den hidtidige tilstand er kun en stadig kilde til kritik fra modstanderne af socialismen og rammer også venstrefløjen selv. Imidlertid hilser de blot alle reformer velkommen, som kommer "fra oven “, fra SUKP's ledelse, for kun her 
finder de kontinuiteten garanteret uden uventede eksplosioner og rystelser, som ville hensatte de vestlige kommunistiske partier og den vestlige venstrefløj i det vanskelige dilemma at skulle afgøre, hvem de skulle gå med - ledelsen eller masserne? Det viger de tilbage for, og de bliver forstyrret af afvigernes, den illegale oppositions protester, af revolterne og masseopstandene, for de afslører offentligt og brutalt realiteten i USSR og de østeuropaiske lande, de modbeviser illusionen om en "positiv tendens " - og alt dette til trods for den kendsgerning, at den største del af oppositionen $i$ USSR og Østeuropa bekender sig til de samme paroler og programmer som de vestlige kommunister og den vestlige venstrefløj (selvforvaltning, ytringsfrihed, uafhængige fagforeninger, adgang tilinformation, frihed til at bosætte sig, hvor man vil, national uafhængighed osv.). Det, som kommunister i Vesteuropa anerkender som progressivt og socialistisk, bliver i USSR og de østeuropæiske lande fordømt af bureaukratiet som "kontrarevolutionært « og »antisocialistisk «, og når kommunister og socialister i Østeuropa bekender sig til "Union de la gauche«s program (Frankrig) eller det spanske kommunistpartis program, bliver de idømt langvarige fængselsstraffe (f.eks. Hübl, Sabata, Müller og andre i Tjekkoslovakiet).

Netop den omstændighed, at man ikke vil forstå, at den sovjetiske og østeuropæiske socialistiske opposition er det vesteuropæiske venstres logiske forbundsfælle, manglen på støtte til denne opposition fra vestlige kommunister og socialister og venstrefløj skaber forvirring i oppositionens rækker, og fører desuden til, at en del af den i fortvivlelse eller på grund af manglende kendskab til situationen vender sig derhen, hvor den får støtte eller i det mindste publicity. Det er klart, at det på det grundlag er muligt at kritisere den sovjetiske opposition, men det er i første række det vesteuropæiske venstre, som er skyld i det, i og med at det forholder sig ligegyldigt til, hvad der sker i USSR og Østeuropa.

På den anden side må den sovjetiske opposition naturligvis også indse, hvem der på langt sigt er dens virkelige forbundsfæller. Det er heller ikke tilfældigt, at der netop i dette spørgsmål opstod en livlig meningsudveksling mellem akademimedlem Sacharov og Roy Medvedev. Mens Sacharov tror, at det vil være en betingelse for at udfolde økonomiske forbindelser mellem USSR og vesten, at der sker en liberalisering af forholdene i USSR, og at de vestlige regeringer derfor vil lægge pres på den sovjetiske ledelse og tvinge den til indrømmelser, så mener Medvedev derimod, at liberaliseringen først vil komme i kølvandet på udfoldelsen af økonomiske forbindelser og den internationale afspænding, og at man derfor 
ikke skal hæmme denne proces gennem ultimative krav, men tværtimod understøtte den på enhver måde.

Den nyligt opnåede aftale mellem Moskva og Washington om at liberalisere udvandringen fra USSR mod, at USSR blev bevilget en mest-begunstiget-nation-klausul, gav imidlertid Sacharov delvist ret $\mathrm{i}$, at man kan tvinge den sovjetiske ledelse til indrømmelser ved pres udefra. Men Medvedev har helt klart ret, når han siger, at den internationale situation kun kan skabe gunstigere betingelser, men at demokratiseringen i USSR nødvendigvis må være resultat af de indre kræfters kamp. Denne kraft kan kun den sovjetiske socialistiske opposition udgøre, som wi og med at den ikke er bundet af noget ansvar for de forløbne årtiers forbrydelser, objektivt kan vurdere både vores samfunds fortid og fremtid og bedre udarbejde de socialistiske og demokratiske alternativer, som det kan udfolde sig i « (Medvedev, 20/5 1974).

$\mathrm{Nu}$ gælder det om, at venstrefløjen i vesten erkender den betydning, som den socialistiske opposition i USSR og Østeuropa - eller kimene til den - har både for socialistiske forandringer i ost og for dens egen kamp for et socialistisk alternativ til kapitalismen. Det er tilstrækkeligt at minde om, hvor dy.rt den kommunistiske og socialistiske verdensbevægelse må bøde for alle USSR's "deformeringer " og "fejltagelser «, og hvordan den "reale socialismes « nuværende tilstand langt snarere virker som hæmsko end som inspiration for dem, som arbejder for socialismen som et retfærdigere samfund. Det er tilstrækkeligt at nævne sådanne "åbne sår “ som ekskommunikeringen af Jugoslavien i 1948, interventionen i Ungarn i 1956 og invasionen i Tjekkoslovakiet i 1968. Ingen reaktionær eller imperialistisk propaganda har nogensinde voldt socialismen større skade. Hovedproblemet ligger ikke i, at reaktionen udnytter disse "fejl ", men i, at de overhovedet er mulige, at de bliver ved med at gentage sig.

Hvordan kan venstrefløjen i vesten give udtryk for sin solidaritet? Hvad forventer den sovjetiske og esteuropæiske opposition af venstrefløjen i vesten?

Forst og fremmest at man holder op med "diplomatisk « at tale om, at man "ikke vil blande sig i USSR's indre anliggender" - ikkeindblanding kan gælde $\mathrm{i}$ forholdet mellem stater, men bor ikke gælde i forholdet mellem socialister; desuden en videnskabelig, seriøs og objektiv diskussion af det socialistiske samfunds væsen og karakter for i denne sammenhæng at analysere det stade, som systemerne i USSR og de østeuropæiske lande nu står på. (Det forudsætter naturligvis, at man bryder med alle »tabuer« og taktiske eller valghensyn.) 
Denne diskussion burde føres på videnskabelige institutter, på seminarer og kollokvier og på tryk i de tidsskrifter, som venstrefløjen råder over. Alle venstrefløjens teoretikere burde deltage - hvadenten de er kommunister eller socialister eller trotskister eller tilhører det ny venstre, simpelthen alle, som ser et alternativ til det kapitalistiske samfund i socialismen.

Det er overordentligt vigtigt, at også marxistiske videnskabsmænd - sociologer, politologer, filosoffer, historikere, økonomer osv. fra USSR og de østeuropæiske lande får mulighed for at deltage $\mathrm{i}$ denne diskussion, især dem, der ikke må undervise, arbejde videnskabeligt og offentliggøre deres skrifter i USSR og andre lande, fordi de tilhører oppositionen eller har kritiske standpunkter. Ved på denne måde at sammenknytte den teoretiske rigdom med den praktiske erfaring ville man berige den socialistiske bevægelse $i$ verden med en uhyre rigdom af viden, nye impulser og erfaringer, som ellers tilintetgøres af den nuværende repressive politik i USSR og andre østeuropæiske lande, hvilket vil volde uvurderlige skader. Kun en sådan konfrontation mellem forestillingerne om det fremtidige socialistiske samfund i vest og erfaringerne fra den »bestående socialismes« deformerede praksis i øst vil gøre det muligt at undgå at gentage fejlene og udarbejde reelle alternativer.

Det ville være en stor hjælp, hvis afhandlinger af respræsentanter for den sovjetiske og østeuropæiske opposition offentliggjordes i de vestlige venstrefløjstidsskrifter, og hvis der udfoldedes en diskussion om disse anskuelser. Derved ville den vestlige venstrefløj bedre forstå den østlige oppositions standpunkter og tænkemåder, og den østlige opposition ville til gengæld bedre forstå den vestlige venstrefløjs holdning, hvilket ville bidrage til, at man gensidigt lærte hinanden bedre at kende og tilnærmede sig til hinanden uden på nogen måde at udelukke polemikker. En ideel løsning ville udgivelsen af et internationalt tidsskrift være, som skulle behandle problematikken om socialistiske alternativer $i$ vest og også $i$ øst og vise sammenhængen i denne kamp. Inden denne tanke kan realiseres, måtte man støtte de socialistiske oppositions-tidsskrifter, som allerede eksisterer, og som kæmper med store problemer.

Diskussionen mellem G. Grass og Sinjavski for et stykke tid siden viste, hvor svært det er $\mathrm{i}$ vest at undgå politisk at udbytte oppositionen i øst. Man kan ganske vist bebrejde mange sovjetiske oppositionelle, at de offentliggør skrifter på forlag, som f.eks. tilhører Springer-koncernen. Men sådan en bebrejdelse er ensbetydende med, at bringe dem til tavshed, hvis man ikke kan eller ikke vil tilbyde dem nogen alternative muligheder for offentliggørelse. Man må erkende, at det politiske højre foreløbig har forstået be- 
tydningen af oppositionen i USSR langt bedre end venstrefløjen, og at det også har forstået at tilbyde praktisk hjælp, mens der hos en del af venstrefløjen gør sig en usikkerhed gældende på, om ik ke en støtte til den sovjetiske opposition eller blot kontakt med den ligegyldig i hvilken form - kan forstyrre realiseringen af møstpolitikken « og de gensidige forbindelser mellem øst og vest.

Det gælder også mulighederne for at offentliggøre manuskripter af forfattere fra USSR og andre osteuropæiske lande, som hjemme er dømt til tavshed, og som hidtil har haft meget svært ved at finde forlæggere i vesten, skønt deres arbejder uden tvivl ville betyde en berigelse af den socialistiske tænkning. Desuden ville man på den måde forhindre den praktiske likvidering af dem.

Det vigtigste overhovedet er, at repræsentanterne for venstrefløjen til enhver tid entydigt fordømmer alle former og udtryk for repression i USSR og de østeuropæiske lande med samme beslutsomhed, som de fordømmer repressionen af progressive kræfter i de kapitalistiske lande. Vi hører tit det synspunkt, at man jo ikke kan sammenligne repressionen i USSR med repressionen i Spanien eller i Brasilien eller i Chile. Det er klart, at der er en forskel her, men den ligger forst og fremmest $i$, at anvendelsen af administrative metoder og politi-repression i de lande, som kalder sig socialistiske, tilføjer socialismen større skade end repressionen i de kapitalistiske lande. Pinochet erklærer jo ikke, at han vil »hjælpe de socialistiske kræfter « med sin repression, som de nuværende ledere i Sovjet netop begrunder deres repression med.

Det, det drejer sig om i den forbindelse, er ikke blot konkrete aktioner, som kan redde oppositionens medlemmer fra de strengeste straffe, og ikke blot den moralske hjælp og solidaritet, som venstrefløjen derved kan vise den socialistiske opposition i USSR og de østeuropæiske lande. Det drejer sig først og fremmest om, hvilken grundlæggende holdning venstrepartierne og venstrekræfterne indtager til ideen om socialismen som et samfund, som vil give borgerne flere friheder end det borgerlige parlamentariske demokrati. Det drejer sig om intet mindre end at lade socialismen vende tilbage til sine oprindelige idealer, som den har fjernet sig fra, og om at forlene de programmer og erklæringer fra venstrepartierne med troværdighed, som i dag i vesten hævder, at de ønsker en "anden", "bedre" socialisme. En sådan holdning vil ikke kun gavne den socialistiske opposition i Østeuropa, men også socialismens sag $i$ vesten og $i$ hele verden.

Det er især vigtigt, at venstrefløjen $i$ vest forsiår betydningen af den sovjetiske oppositions krav om sikring af ytrings- og forsamlingsfrihed, frihed til kritik og til adgang til informationer. Den 
vestlige venstrefløj undervurderer ofte vigtigheden af dette krav eller regner det for et specielt krav fra de intellektuelle, som ikke angår arbejderne og bønderne. Erfaringen fra den samlede udvikling i USSR og de osteuropæiske lande har imidlertid bevist, at netop dette krav er den grundlæggende betingelse for enhver demokratiseringsproces. Uden at det realiseres - om det så kun bliver delvist - kan der ikke ske nogen genoplivning af det politiske liv, den arbejdende befolkning kan ikke indtage nogen selvstændig holdning til landets grundlæggende livsspørgsmål, og de henfalder derfor til afhængighed af de bureaukratiske eliter, som taler i deres navn. Uden at disse friheder realiseres, kan der ikke ske nogen positive grundlæggende forandringer i USSR og de osteuropæiske lande.

Ikke udvandring for oppositionens medlemmer, men derimod frihed og mulighed for at offentliggøre deres meninger i deres eget land og for at deltage ligeberettiget $\mathrm{i}$ det politiske liv - det burde være et af venstrefløjens hovedkrav. Det er nødvendigt også at overbevise den regerende gruppe i USSR om, at de ikke vil skade socialismen ved at indfore disse friheder - specielt ikke ved at legalisere den socialistiske opposition, men at virkeligt solidariske bånd $\mathrm{og}$ internationalisme tværtimod ikke er mulig uden disse forholdsregler.

Venstrefløjen er i dag stærk nok til at kunne lægge politisk pres på den sovjetiske ledelse for at få den til at revidere sin politik over for folk, som har afvigende forestillinger om opbygningen af socialismen. Dette er den i sin gode ret til - ud fra den så ofte citerede og besungne internationale solidaritet mellem alle, der kæmper for de socialistiske tankers sejr. Det er dens ret og dens pligt, for den nuværende tilstand i USSR komplicerer og svækker ikke blot venstrefløjens politiske arbejde i vest, men først og fremmest blokerer og hindrer den muligheden for enhver form for grundlæggende ændringer af det kapitalistiske samfund og nedfryser den politiske status quo $i$ verden.

I den forbindelse må venstrefløjen overvinde fordomme som, at enhver radikal kritik af den nuværende ledelse i USSR "hjælper reaktionen “ og sætter den, der kritiserer, i et "antisocialistisk « lys. Det er en fuldkommen falsk teori, som er udtænkt af det nuværende regerende bureaukrati, som vil identificere socialismens interesser med deres egne privilegiers og deres stormagtspolitiks interesser. En sådan kritik på marxistisk grundlag er tværtimod i socialismens interesse, ikke kun i vest, men også i Sovjetunionen selv. En sådan kritik lægger heller ikke på nogen måde hindringer $\mathrm{i}$ vejen for, at der kan udfolde sig normale politiske, økonomiske, 
kulturelle og videnskabelige forbindelser mellem USSR og de vestlige lande, hvilket uden tvivl er en positiv faktor i den internationale udvikling. Men behovet for at skaffe råstoffer, for at eksportere teknologi, for at begrænse oprustningen og for at slutte gensidigt fordelagtige kompromisser, må ikke være prisen for, at socialister og demokrater bringes til tavshed - for at arven fra Oktoberrevolutionen likvideres.

Der er næsten forløbet et halvt århundrede, siden den første sovjetiske borger blev deporteret over grænsen af politiske grunde: Den deporterede dengang var en af hovedaktørerne i Oktoberrevolutionen og Lenins nærmeste medarbejder - Leo Trotskij. Hans politiske udvikling var meget righoldig, og han bærer bestemt også sin del af ansvaret for den tragiske udvikling efter Oktoberrevolutionen; men der er ingen tvivl om, at han endnu, mens han deltog $i$ den politiske magt, og i de år, hvor han lidt efter lidt blev udelukket fra det politiske liv, begyndte at forstå, at "proletariatets diktatur « under Stalins ledelse ville ændre sig til »apparatets diktatur «, som ville forråde revolutionen og fratage den dens virkelige indhold. Derfor holdt han ikke op med at kalde til kamp mod denne udvikling fra den radikale socialismes positioner fra det øjeblik, han landede som deporteret i det fremmede, og lige til sin død fortsatte han med at opfordre til tilbagevenden til sovjetregeringens grundsætninger. I vesten blev han afvist af højrefløjen og også af en betragtelig del af venstrefløjen, som ikke ville gøre sig nogen tanker om indholdet af hans tragedie, som i øvrigt ikke kun var hans tragedie, men en hel generation af bolsjevikkers tragedie. $\mathrm{Nu}$ et halvt århundrede senere følger forfatteren Alexander Solsjenitsyn efter Leo Trotskij som den anden sovjetiske borger, der blev deporteret af politiske grunde, og efter ham snesevis, hundreder og måske endda tusinder af flere mindre kendte, som endnu vil komme. Det er forståeligt, at venstrefløjen i vest ville ønske, at også disse mennesker skulle bringe et lignende budskab om den radikale socialisme, og at de $\mathrm{i}$ deres kamp eller fortvivlelse skulle være forblevet tro mod arven fra Oktoberrevolutionen. Men de glemmer, at de livserfaringer, som disse nye landsforviste har gjort, er fuldstændig modsatte af Trotskijs og hans kammeraters erfaringer. De er vokset op i det stalinistiske diktaturs Rusland, de har ikke kendt den fascinerende revolutionstid, de stødte sammen med den bureaukratiske dogmatisme, mange af dem har tilbragt deres bedste år i koncentrationslejre og fængsler, og i de sidste år har de levet $\mathrm{i}$ "ghettoen « for dem, der er bragt til tavshed og udelukket fra det offentlige liv. Kan det undre, at de ikke kalder til genoplivning af sovjetternes magt? At de tvivler på socialismen - på den socia- 
lisme, som de har lært at kende (uden noget alternativ -, mange indrømmer, at netop det "tjekkiske forårs « nederlag, som endnu kunne have reddet deres tro på socialismen, blev deres definitive skuffelse)? At de har illusioner om det vestlige samfund, hvor de dog ser, at der er mulighed for politisk og kulturelt liv for enhver opposition og for en afgørende større frihed end den, som det sovjetiske bureaukrati tilstår sine undersåtter? At de i første række vender sig derhen hvor de finder mere forståelse for deres fordums lidelser og deres fremtidige kamp?

For en person fra den vestlige venstrefløj, der er vant til en klar opdeling efter bestemte kriterier, er det svært at forstå denne forandring, som i løbet af det sidste halve århundrede er sket $\mathrm{i}$ hovederne på sovjetiske borgere. Alt dette gælder nemlig ikke kun for dem, som nu kommer til vesten, men også for dem, som bliver $\mathrm{i}$ landet. At der er ved at ske en langsom ændring af denne situation, at der er ved at opstå kim til politisk tænken, at menneskene igen stiller sig spørgsmålet om revolutionens, socialismens og demokratiets indhold, at de begynder at tvivle på det, som de får at vide, de skal tro på, og begynder at søge alternativer - alt dette har folk som Grigorenko, Medvedev, Jakimovitch og and re fra den socialistiske strømning i oppositionen ydet deres vigtige bidrag til men også Solsjenitsyn, Bukovskij, Sinjavskij, Amalrik, Litvinov, Daniel, Martchenko, Jessenin-Volpin, Tcadlidse, Nekrassov, Maximov og hundreder af andre kendte og ukendte, socialister, demokrater, kristne, jøder, nationalister fra de små republikker - som alle har indset, "kun den kan tie, som ikke kan tale«.

Vil dette smertelige og modsætningsfyldte budskab blive forstået af den vestlige venstrefløj, og vil venstrefløjer drage de rigtige konklusioner af det? Eller må den vestlige venstrefløj gennemleve de samme tragiske erfaringer på sin egen krop, før den forstår betydningen af dem? Vil venstrefløjen i USSR og Østeuropa finde sin partner i vest eller vil den blive overladt til sin skæbne? Det er spørgsmål, som jeg endnu ikke tør give svaret på. Jeg ved kun, at meget afhænger af svaret på dem, først og fremmest socialismens skæbne i verden.

(Fra tjekkisk af Jiri Starek) fra tysk af Nina Lykke.

Jiri Pelikan (f. 1923), journalist, indtil 1968 generaldirektør for det tjekkoslovakiske fjernsyn; medlem af det tjekkiske parlament; medlem af det tjekkoslovakiske kommunistpartis centralkomité, afsat efter invasionen i 1968; lever nu som skribent i exil i Rom. I Kontrast 42, 1973, er oversat artiklen: Arbeiderråd i Tsjekkoslovakia, The Struggle for Socialism in Czechoslovakia (interview), New Left Review 71 , 1972. 